\title{
POTENSI PENERAPAN PRODUKSI BERSIH PADA RUMAH POTONG HEWAN (RPH) KOTA JAMBI
}

Winny Laura Christina Hutagalung ${ }^{1}$, Miftahul Jannah SB $^{1}$, dan Rinaldi ${ }^{1}$

${ }^{1}$ Prodi Teknik Lingkungan Universitas Jambi

Pondok Meja, Jambi

Email Penulis: winnylaura@yahoo.co.id

\section{Info Artikel}

Diterima: 03 Desember 2020

Disetujui: 27 Januari 2021

Dipublikasikan: 13 Maret 2021

\begin{abstract}
Abstrak
Penelitian ini dilakukan untuk menganalisis potensi pencemaran dan pemanfaatan limbah cair dan limbah padat dari UPTD Rumah Potong Hewan (RPH) Kota Jambi, serta penerapan produksi bersih bersih berdasarkan Guidance Manual: How to Establish and Operate Cleaner Production Centres. Parameter yang diambil adalah BOD, COD, TSS, Minyak \& Lemak, pH. Limbah padat berupa $\mathrm{C}$ dan $\mathrm{N}$, serta wawancara dengan pekerja. Hasil penelitian menunjukan kualitas BOD $11.280 \mathrm{mg} / \mathrm{l}$, COD $17.110 \mathrm{mg} / \mathrm{l}$, TSS $2.300 \mathrm{mg} / \mathrm{l}$, Minyak \& Lemak $168 \mathrm{mg} / \mathrm{l}$ berada di atas standar baku mutu yang berpotensi mencemari lingkungan kecuali pH 7,9 yang masih dibawah baku mutu. Darah dapat berpotensi sebagai pakan ternak sekitar $60 \mathrm{~kg} / \mathrm{hari}$, urine menjadi pupuk organik cair sekitar 900 liter. Limbah padat berpotensi menjadi Pembangkit Listrik Tenaga Biogas (PLTB) sekitar 11,28 kWh/hari dan pupuk organik/kompos yang bisa meningkatkan produktivitas pertanian sekitar $180 \mathrm{~kg} /$ hari. kesimpulan yang dapat diambil untuk mengoptimalkan produksi bersih, yakni: pemasangan keran, pemasangan water sprayer gun, penggunaan masker, dan pembuatan poster mengenai produksi dengan penghematan mencapai Rp 3.718.578,08/tahun.
\end{abstract}

Kata kunci: Limbah; Pencemaran; Produksi Bersih

\begin{abstract}
:
The purpose of this study was to analyze the potential pollution and utilization of liquid waste and solid waste from the UPTD Slaughterhouse (RPH) of the City of Jambi, as well as the application of clean production based on the Guidance Manual: How to Establish and Operate Cleaner Production Centers. The study was conducted by survey method, the parameters taken were BOD, $C O D$, TSS, Oil \& Fat, $p H$. Solid waste in the form of $C$ and $N$, and interviews with workers. The results showed that the quality of BOD was 11,280 mg/l, COD 17,110 mg/l, TSS 2,300 mg/l, Oil \& Fat $168 \mathrm{mg} / \mathrm{l}$ were above the quality standard that could potentially pollute the environment except $p H 7.9$ which was still below the quality standard. Blood can potentially be used as animal feed around $60 \mathrm{~kg} /$ day, urine into liquid organic fertilizer around 900 liters. Solid waste has the potential to become a Biogas Power Plant (PLTB) around $11.28 \mathrm{kWh} /$ day and organic fertilizer / compost which can increase agricultural productivity around $180 \mathrm{~kg} /$ day. conclusions that can be drawn to optimize clean production, namely: installation of taps, installation of water sprayer gun, use of masks, and making posters about production with savings reaching $R p$ 3,718,578.08 / years.

Keywords: Waste; Pollution; Cleaner Production
\end{abstract}

\section{Pendahuluan}

UPTD RPH Kota Jambi menghasilkan limbah yang dapat mencemari lingkungan sekitar, hal ini dikarenakan limbah yang dihasilkan mengandung bahan organik yang tinggi. Masalah yang terjadi pada UPTD RPH Kota Jambi adalah tidak memiliki pengolahan limbah yang baik, hanya memiliki kolam penampungan yang sudah lama mengalami kerusakan sehingga tidak befungsi dengan baik. Produksi bersih dapat diterapkan pada UPTD RPH Kota Jambi untuk mengatasi permasalahan limbah dengan 
memanfaatkan limbah cair dan limbah padat yang dihasilkan. Penerapan produksi bersih diharapkan agar limbah yang terjadi dapat ditekan seminimal mungkin, sehingga tidak lagi mencemari lingkungan bahkan dapat bermanfaat menjadi suatu produk baru. Berdasarkan uraian di atas, permasalahan maka tujuan dari penelitian ini adalah untuk menganalisis potensi pencemaran dan pemanfaatan limbah cair dan padat dari UPTD Rumah Potong Hewan (RPH) Kota Jambi; serta untuk menganalisis potensi penerapan produksi bersih berdasarkan Guidance Manual: How Establish and Operate Cleaner Production.

\section{Metode Penelitian}

Penelitian ini dilaksanakan di UPTD Rumah Potong Hewan Kota Jambi. Objek pada penelitian ini adalah jumlah timbulan limbah yang dihasilkan di sumber, diketahui massa dan volume limbah yang dihasilkan UPTD RPH Kota Jambi; kualitas air keluaran unit pengolahan limbah cair UPTD RPH Kota Jambi dilakukan dengan melakukan analisis laboratorium; Pekerja, akan dijadikan narasumber dalam penelitian; jumlah hewan, dihitung jumlah hewan yang dipotong setiap harinya dan hewan yang ada di kandang.

Tabel 1. Jenis Data Penelitian

\begin{tabular}{ll}
\hline Jenis Data & Teknik Analisis Data \\
\hline $\begin{array}{l}\text { Kualitas air limbah RPH Kota } \\
\text { Jambi }\end{array}$ & $\begin{array}{l}\text { Melakukan pengujian parameter limbah } \\
\text { di laboratorium }\end{array}$ \\
Kualitas limbah padat Kota Jambi & $\begin{array}{l}\text { Melakukan pengujian parameter C dan N } \\
\text { di laboratorium }\end{array}$ \\
Debit kebutuhan air bersih & $\begin{array}{l}\text { Melakukan pengukuran debit pada } \\
\text { proses kegiatan }\end{array}$ \\
Debit air limbah UPTD RPH Kota & $\begin{array}{l}\text { Melakukan pengukuran debit pada luas } \\
\text { penampang basah } \\
\text { Jambi }\end{array}$ \\
Produksi bersih & $\begin{array}{l}\text { Berdasarkan Guidance Manual: } \\
\text { Cleaner Production Centres } \\
\text { (UNIDO dan UNEP) }\end{array}$ \\
&
\end{tabular}

\section{Hasil Penelitian dan Pembahasan}

Limbah cair dari rumah potong hewan umumnya memiliki kandungan $\mathrm{pH}, \mathrm{BOD}$, COD, TSS, Minyak dan Lemak. Parameter tersebut akan mengganggu lingkungan sekitar apabila bersifat berlebihan. Hasil uji limbah cair rumah potong hewan Kota Jambi dapat dilihat pada Tabel 2.

Tabel 2. Baku Mutu Limbah Rumah Potong Hewan

\begin{tabular}{llllll}
\hline Parameter & Satuan & Hasil Uji & Spesifikasi Metode & Baku Mutu & Ket \\
\hline pH & - & 7,9 & SNI 06-6989.11-2004 & $6-9$ & Memenuhi \\
BOD & mg/L & 11280 & SNI 6989-72-2009 & 150 & Tidak \\
& & & & & Memenuhi \\
COD & mg/L & 17110 & SNI 6989-2-2009 & 400 & $\begin{array}{l}\text { Tidak } \\
\text { Memenuhi }\end{array}$ \\
& & & & &
\end{tabular}




\begin{tabular}{lccccc}
\hline TSS & mg/L & 2300 & SNI 06-6989.27-2005 & 300 & $\begin{array}{l}\text { Tidak } \\
\text { Memenuhi }\end{array}$ \\
$\begin{array}{l}\text { Minyak dan } \\
\begin{array}{l}\text { Lemak } \\
\text { (M/L) }\end{array}\end{array}$ & mg/L & 168 & SNI 6989-10-2011 & 25 & Tidak \\
\hline
\end{tabular}

Nilai pH pada pengujian mencapai 7.9, masih memenuhi baku mutu. Nilai $\mathrm{pH}$ menunjukkan tingkat keasaman atau kekuatan asam dan basa dalam air. Besarnya $\mathrm{pH}$ air mempengaruhi kelarutan dan bentuk senyawa kimia dalam badan air. Perubahan $\mathrm{pH}$ dalam air akan mempengaruhi perubahan dan aktivitas biologis (Wibowo,2013). Darsono (1994) menyatakan bahwa perubahan keasaman pada air limbah baik kearah basa ( $\mathrm{pH}$ naik) ataupun kearah asam ( $\mathrm{pH}$ turun), akan sangat berbahaya bagi kelangsungan hidup ikan dan fauna air lainnya. Selain itu air limbah yang memiliki $\mathrm{pH}$ sangat rendah bersifat korosif dan sering mengakibatkan pipa besi menjadi berkarat. Kadar BOD menunjukan nilai $11280 \mathrm{mg} / \mathrm{l}$ yaitu sekitar 75 kali lipat dari baku mutu.

Effendi (2003) menyatakan bahwa semakin besar BOD di dalam air menunjukkan semakin besar pula kandungan bahan organik. Jika limbah dengan nilai BOD tinggi dibuang ke perairan maka mikroorganisme yang terdapat dalam perairan akan mulai mendegradasi bahan organik dalam limbah tersebut. Proses ini akan menghabiskan oksigen dalam perairan. Bila kadar oksigen berkurang akan mengganggu kelangsungan hidup ikan dan fauna perairan lainnya (Fardiaz, dalam Dilla 2015).Kadar COD menunjukkan nilai $17110 \mathrm{mg} / \mathrm{l}$ yaitu sekitar 42 kali lipat lebih tinggi dari baku mutu. Tingginya kadar COD menunjukkan tingginya jumlah oksigen yang dibutuhkan untuk mengoksidasi seluruh bahan kimia baik organik maupun anorganik di dalam sampel air limbah.

Kadar COD dan BOD yang tinggi jika dibuang langsung ke lingkungan akan melebihi kemampuan asimilasi di dalam aliran air maka bakteri akan tumbuh dengan cepat dan mengkonsumsi semua oksigen terlarut dan akibatnya akan tercipta kondisi anaerobik (Triatmojo, 2008). Kadar TSS mencapai $2300 \mathrm{mg} / \mathrm{l}$ yaitu sekitar 7 kali lipat melebihi baku mutu, kadar TSS yang tinggi akan menimbulkan pencemaran perairan. Tingginya kadar TSS yang melebihi baku mutu pada semua jenis air limbah diduga akibat kotoran isi rumen, isi lambung, isi usus, darah dan bahan lainya. Keadaaan ini tampak pada air limbah RPH sapi berwarna coklat sampai merah tua serta mengeluarkan bau amis sampai bau busuk.

Zat padat tersuspensi yang mengandung zat-zat organik pada umumnya terdiri dari protein, gangguan, dan bakteri. Kadar minyak dan lemak mencapai $168 \mathrm{mg} / \mathrm{l}$ yaitu sekitar 6 kali lipat melebihi baku mutu. Hal ini disebabkan karena kebiasaan pengguna RPH yang membuang bagian lemak pada saat membersihkan bagian dalam rumen dengan jumlah dan frekuesi waktu yang berbeda pada setiap ulangan ke ali ran air limbah. Minyak dan lemak dapat mempengaruhi aktifitas mikroba dan membentuk lapisan di permukaan cairan limbah sehingga menghambat proses oksidasi pada kondisi aerobik. Minyak yang menutupi permukaan air akan menghalangi penetrasi sinar matahari ke dalam air.

Selain itu, lapisan minyak juga dapat mengurangi konsentrasi oksigen terlarut dalam air karena fiksasi oksigen bebas menjadi terhambat. Akibatnya, terjadi ketidakseimbangan rantai makanan dalam air (Nugroho, 2006). Secara keseluruhan dari data yang ada pada Tabel 5.2 menunjukkan bahwa berdasarkan Peraturan Menteri Lingkungan Hidup No. 5 Tahun 2014 tentang baku mutu air limbah bagi kegiatan RPH, kualitas BOD, COD, TSS, minyak \& lemak dari RPH Kota Jambi berada diatas baku mutu kecuali nilai $\mathrm{pH}$ yang sudah memenuhi baku mutu. Pada RPH Kota Jambi perlu adanya Instalasi Pengolahan Air Limbah (IPAL) untuk menurunkan kadar pencemar pada lingkungan sekitar RPH Kota Jambi.

Pemanfaatan limbah cair bertujuan untuk mengubah efek limbah cair yang negatif menjadi bahan yang memiliki nilai fungsional yang positif. Limbah cair berupa darah dapat dimanfaatkan menjadi pakan ternak. Pada penelitian R. F. Ramadhan,dkk (2015) pemanfaatan limbah cair darah dari RPH dijadikan sebagai pakan ternak dengan metode penyerapan (pencampuran). Menurut Odunsi dalam R.F. Ramadhan (2015) telah melakukan pencampuran darah sapi dengan cairan rumen untuk 
menggantikan bungkil kacang tanah dan tepung ikan dalam ransum ayam petelur. Darah segar dan cairan rumen ditimbang dengan rasio perbandingan 1:1, kemudian dicampurkan dan direbus selama 90 menit sambil diaduk agar tercampur merata. Selanjutnya campuran darah dan cairan rumen dijemur di bawah sinar matahari sampai kandungan airnya mencapai $15 \%$, kemudian digiling. penggunaan campuran darah dan cairan rumen sebagai bahan pakan tidak mendukung sepenuhnya dalam meningkatkan performa. Pengolahan tepung darah dengan cara penyerapan ini juga dapat mempercepat proses pengeringan yang dapat mempersingkat waktu pembuatan tepung darah dan juga dapat meningkatkan kualitas nutrisi dari limbah pertanian yang digunakan sebagai bahan penyerap darah.

Pada proses pembuatan tepung darah, untuk mendapatkan $1 \mathrm{~kg}$ tepung darah memerlukan $5 \mathrm{~kg}$ darah segar (Jamila, 2010). Jika pada UPTD RPH Kota Jambi memotong ternak 15 ekor perhari dengan jumlah darah yang dihasilkan 20 liter per ekor, maka tepung darah yang dapat dihasilkan sekitar $60 \mathrm{~kg} / \mathrm{hari}$.Satu ekor sapi dapat menghasilkan 10-15 liter urine perhari. Urine sapi berpotensi dijadikan sebagai pupuk organik cair yang memiliki 3 fungsi yaitu sebagai pupuk cair bagi tanaman, sebagai zat pengatur tumbuh tanaman, dan sebagai pestisida nabati. Untuk menghasilkan pupuk cair sebanyak 80 liter, dibutuhkan urine sebanyak 40 liter (Suryanto, 2013). Jika pada UPTD RPH memotong ternak 15 ekor perhari dan sis 15 ekor yang ada di kandang, maka urine yang dihasilkan sebanyak 450 liter perhari dengan pupuk organik cair yang dihasilkan sekitar 900 liter.

Pemanfaatan limbah padat bertujuan untuk mengubah efek limbah padat yang negatif menjadi bahan yang memiliki nilai fungsional yang positif. Limbah padat RPH dapat dimanfaatkan sebagai sumber energi Pembangkit Listrik Tenaga Biogas (PLTB). Energi biogas sangat potensial untuk dikembangkan kerena produksi biogas peternakan ditunjang oleh kondisi yang kondusif dari perkembangkan dunia peternakan sapi di Indonesia saat ini. Disamping itu, kenaikan tarif listrik, kenaikan harga LPG (Liquefied Petroleum Gas), premium, minyak tanah, minyak solar, minyak diesel dan minyak bakar telah mendorong pengembangan sumber energi elternatif yang murah, berkelanjutan dan ramah lingkungan (Nurhasanah dkk., 2006). Berdasarkan sumber Depatemen Pertanian, umtuk mengetahui konversi biogas menjadi energi lain dapat dilihat pada Tabel 3. Dengan demikian, potensi energi listrik yang dihasilkan pada kotoran ternak yang telah diolah adalah 2,4 $\mathrm{m} 3 /$ hari $\mathrm{x} 4,7 \mathrm{kWh} / \mathrm{m} 3=11,28 \mathrm{kWh} / \mathrm{hari}$.

Tabel 3. Konversi Biogas

\begin{tabular}{ll}
\hline Penggunaan & Energi $\mathbf{1} \mathbf{~ m}^{\mathbf{3}}$ Biogas \\
\hline Penerangan & Lampu 60-100 watt selama 6 jam \\
Memasak & Memasak 3 jenis makanan untuk 5-6 orang \\
Tenaga & Menjalankan motor 1 HP selama 2 jam \\
Bahan Bakar & $0,46 \mathrm{~kg}$ LPG \\
Listrik & $4,7 \mathrm{kWh}$ energi listri \\
\hline
\end{tabular}

\section{Kesimpulan}

Kesimpulan dari penelitian ini adalah:

a) Secara keseluruhan dari data yang ada menunjukkan bahwa berdasarkan Peraturan Menteri Lingkungan Hidup No. 5 Tahun 2014 tentang baku mutu air limbah bagi kegiatan RPH, kualitas BOD, COD, TSS, , minyak \& lemak dari RPH Kota Jambi berada diatas baku mutu kecuali nilai $\mathrm{pH}$ yang sudah memenuhi baku mutu yang ditetapkan karena di UPTD RPH Kota Jambi belum ada IPAL yang dapat mencemari lingkungan maupun manusia sendiri. Pemanfaatan limbah 
cair bisa menjadi tepung darah sebagai pakan ternak yang berpotensi menghasilkan $60 \mathrm{~kg} / \mathrm{hari}$ tepung darah dan pupuk organik cair yang dihasilkan sekitar 900 liter.

b) Pada UPTD RPH Kota Jambi limbah padat seperti kotoran belum dimanfaatkan secara maksimal hanya diambil atau diangkut oleh petugas yang ingin menjadikan pupuk untuk tanaman mereka, bahkan limbah kotoran dikumpulkan di dalam sebuah tampungan dan isi rumen dialirkan bersama limbah cair. Pembuangan kotoran ternak sembarangan dapat menyebabkan pencemaran pada air, tanah dan udara (bau), serta memberikan dampak pada kualitas lingkungan, kualitas hidup ternak dan dapat memicu konflik sosial.Pemanfaatan limbah padat ini bisa dijadikan sumber energi Pembangkit Listrik Tenaga Biogas (PLTB) dengan potensi 11,28 kWh/hari dan kompos / pupuk organik.sekitar $180 \mathrm{~kg} / \mathrm{hari}$.

c) Pada UPTD Rumah Potong Hewan Kota Jambi belum adanya produksi bersih, maka dari itu perlu untuk merencanakan penerapan sistem produksi bersih berdasarkan Guidance Manual: How to Establish and Operate Cleaner Production Centres dengan beberapa langkah mulai dari perencanaan dan pengorganisasian, pra pengkajian, pengkajian, dan analisis studi kelayakan. Peluang yang dapat diaplikasikan pada penerapan produksi bersih diantaranya: Pemasangan keran pada RPH dengan penghematan Rp 132.100,9/bulan; Pemasangan water sprayer gun pada RPH dengan penghematan Rp291.113,93/bulan.

\section{Daftar Pustaka}

Aini, Sriasih Made, Kisworo Djoko. 2017. Studi Pendahuluan Cemaran Air Limbah Rumah Potoong Hewan di Kota Mataram. Jurnal Ilmu Lingkungan UNDIP

Amaranti. R. Dkk. 2012. Pemanfaatan Kotoran Ternak Menjadi Sumber Energi Alternatif dan Pupuk Organik. Buana Sains Vol 12 No 1:99-104

Badan Pusat Statistik. (2009). Jumlah Ternak yang Dipotong di Rumah Potong Hewan dan Di Luar Rumah Potong Hewan Menurut Provinsi dan Jenis Ternak (Ekor).Diakses: 21 April 2019.https://www.bps.go.id/dynamictable/2015/09/19/914/jumlah-ternakyang-dipotong-di-rumahpotong-hewan-rph-menurut-provinsi-dan-jenisternak-ekor-2008-2017.html

Effendi, H. 2003. Telaah kualitas air bagi pengelola sumber daya dan lingkungan perairan. Yogyakarta. Kanisius.Health Protection Agency, 2007. Ammonia Toxicological Overview. J D Pritchard CHAPD HQ, HPA.

Indrasti, N.S., \& Fauzi, A.M. 2009. Produksi Bersih. Bogor: IPB Press.

Jati Dian Rahayu, Handayani Emilia Farida Budi, Saziati Ochih. 2018. Pengolahan Pupuk Organik Cair Limbah Rumah Potong Hewan Untuk Kelompok Tani Karya Usaha II Kabupaten Kubu Raya. Buletin Al Ribaath, Universitas Muhammadiyah Pontianak.

Kist L.T., dkk. 2009. Cleaner production in the management of water use at a poultry slaughterhouse of Vale do Taquari, Brazil: a case study. Journal of Cleaner Production 17 (2009) 1200-1205

Kliopova I. dkk. 2006. The evaluation of Cleaner Production performance in Lithuanian industries. Journal of Cleaner Production 14 (2006) 1561-1575

Kupusovic T, Midzic S, Silajdzic I, Bjelavac J. Cleaner production measures in small-scale slaughterhouse industry -case study in Bosnia and Herzegovina. Journal of Cleaner Production 15 (2007) 378383

Lewis RJ, Copley GB.2014. Chronic low-level hydrogen sulfide exposure and potential effects on human health: a review of the epidemiological evidence. J Crit Rev Toxicol. 2014; 45(2):1-31. 67 
Maretta, Wahida Fitria Nur, dkk. 2016. Pengaruh Konsentrasi Urine Sapi Brahman (Bos taurus indicus Linn.) Terhadap Pertumbuhan Bibit Cabai Rawit (Capsicum frutescens Linn.). Universitas Negeri Malang.

Nurfifi Sahida, Jafriati, Ardiansyah Ririn Teguh. 2017. Analisis Pengelolaan Limbah UPTD Rumah Pemotongan Hewan (RPH) dan Dampaknya Terhadap Masyarakat Sekitar Kelurahan Anggoeya Kecamatan Poasia Kota Kendari. Jurnal Ilmiah Mahasiswa Kesehatan Masyarakat.OECD. (2000). Reference Manual on Strategic Waste Prevention.

Panjaitan, Susi Irmawati. 2012. Analisis Perhitungan Daya yang dihasilkan dari Kotoran Sapi yang diolah menjadi Biogas di Derah Pinggiran Kota Batam. Universitas Maritim Raja Ali Haji Batam

Padmono Djoko. 2005. Alternatif Pengolahan Limbah Rumah Potong HewanCakung. Badan Pengkajian dan Penerapan Teknologi

Peraturan Menteri Pertanian Republik Indonesia Nomor 13/Permentan/OT.140/1/2010. Persyaratan Rumah Potong Hewan Ruminansia dan Unit Penanganan Daging (Meat Cutting Plant) : Jakarta

Peraturan Menteri Negara Lingkungan Hidup No 02 tahun 2006. Baku Mutu Air Limbah Bagi Kegiatan Rumah Pemotongan Hewan

R. F. Ramadhan, Y. Marlida, Mirzah, dan Wizna. 2015. Metode Pengolahan Darah sebagai Pakan Unggas: Review. Jurnal Peternakan Indonesia, Vol. 17 (1) ISSN 1907-1760

Salamah, Umi. Adriyani, Retno. 2018. Analisis Risiko Kesehatan Pekerja di Rumah Pemotongan Hewan Akibat Pajanan Gas Amonia. Jurnal Kesehatan Lingkungan Vol. 10, No. 1

Sianipar W.S. 2006. Studi Aplikasi Produksi Bersih pada Industri Rumah Pemotongan Hewan (RPH) (Studi Kasus di PT Celmor Perdana Indonesia / PT Elders Indonesia). Bogor : Institut Pertanian Bogor

Sihotang, Dewi Ririn. 2012. Evaluasi Penerapan Teknologi Produksi Bersih di Rumah Pemotongan Hewan (Studi Kasus di Rumah Pemotongan Hewan Cakung). Depok : Universitas Indonesia

Standar Nasional Indonesia (SNI) 3932:2008 Mutu Karkas dan Daging Sapi. 68

St-pierre B, Wright ADG.2017. Implications from distinct sulfate-reducing bacteria populations between cattle manure and digestate in the elucidation of $\mathrm{H} 2 \mathrm{~S}$ production during anaerobic digestion of animal slurry. J Appl Microbiol Biotechnol. 2017; 101(13):1-15.

Suhardjadinata. 2016. Proses Produksi Pupuk Organik Limbah Rumah Potong Hewan dan Sampah Organik. Jurnal Siliwangi Vol.2.No.2 Seri Sains dan Teknologi

Surat Keputusan Menteri Pertanian No.413/Kpts/Tn.310/7/1992. Pemotongan Hewan Potong dan Penanganan Daging Serta Ikutannya. Jakarta

Suzuki K, Takeshi W, Vo Lam. 2001. Consentration and cristalization of posphate, ammonium and mineral in the effluent of biogas digester in the Mekong Delta. Vietnam. Jirean Cantho University, Cantho Vietnam. 16:271-276.

Triatmojo Bambang. 2008. Hidrologi Terapan. Beta Offset, Yogyakarta

UNEP. 2003. Cleaner Production Assessment in Meat Processing.

UNEP dan ISWA. (2002). Training Resource Pack for Hazardous Waste Management in Developing Economies.

UNEP dan UNIDO. 1996. Guidance Manual (How to Establish and Operate Cleaner Production Centres) 